\title{
Package Type Not Applicable
}

National Cancer Institute

\section{Source}

National Cancer Institute. Package Type Not Applicable. NCI Thesaurus. Code C123723.

There is no associated package type. 